\title{
SAFETY IN STUDENT RESIDENCES MATTERS!
}

\author{
N. Gopal* \\ e-mail: gopal@ukzn.ac.za \\ C. van Niekerk* \\ e-mail: caitlinjadevn@gmail.com \\ *Department of Criminology and Forensic Studies \\ University of Kwa-Zulu Natal \\ Durban, South Africa
}

\section{ABSTRACT}

In 2011 Minister Blade Nzimande reported that, "despite a national call for the provision of accessible, decent, safe and academically conducive student accommodation safety in student accommodation in South Africa remains a serious challenge" (cited in, Department of Higher Education and Training 2011). Against the backdrop of the provision of safe student accommodation, this study, through a qualitative research design, examined residence students' experiences of safety and security in student accommodation (residences). Through narrative enquiry the study-generated data from purposively sampled male and female residence students representing undergraduate and postgraduate students. The data points to fears and anxieties of students living in residences enabled by a vulnerable (unsafe) residence environment influenced largely through diminished state resources. The study makes recommendations for state resource investment that promote safe, quality residences to enhance student academic success.

Keywords: students, residences, fears, vulnerabilities, education, academic success, conducive environment, student housing.

\section{INTRODUCTION}

Perusal of South African national databases demonstrate a significant body of literature on student residences in European countries, the United States and some in Australia but a dearth of similar literature in a South African context. The few available studies Eurostudent (2011), Jansen and Dube (2013) and Swartz (1998) however confirm that the quality of student housing is integral to student academic success, and a mechanism to improve the lives of citizens who were excluded from past equal opportunities. Logically a growth in higher education should result in an increased demand for student housing. For instance, during the 1950s and 1960s, when the United States expanded Higher Education, the sector experienced a period of unprecedented growth for student accommodation. This was to cater for the World War II veterans and the large group of "baby boomers” born soon after the war ended (Palmer, Broido 
and Campbell 2008).

Similarly, post 1994 saw an increase in demand for higher education in South Africa. This increase was an attempt to address socio-politico historical inequalities. Higher Education Institutions (HEI's) had to now cater to larger numbers of students requiring university accommodation as more students were studying away from home. Most universities were not capacitated to cater for the increased numbers of students seeking university accommodation. This despite the state promoting higher education in South Africa as a cornerstone to a successful and improved economy that purports to address past discriminatory socio-economic practices.

Given its marginalisation of the vast majority of eligible students to higher education South African HEI's had an integral role to play not just in providing access to lecture hall education but making that access possible for those who are geographically far removed from HEI's. HEI's has thus had a dual role to play - providing quality education and acting in locoparentis to students living in university residences. As such Pascarella and Terenzini, along with Blimling (1994) (quoted in Graham, Hurtado and Gonyea 2016) assert "living on campus will maximize opportunities for social, cultural, and extracurricular involvement, and this increased involvement will account for residential living's impact on various indices of student development”. Conversely, though some researchers (Blimling 1989; Pascarella and Terenzini 2005; Strayhorn and Mullins 2012) (quoted in Graham, Hurtado and Gonyea 2016) purport that, "While residence halls have the potential to foster positive interactions with students from diverse backgrounds, they alternatively can encourage groupthink and provide a space for hostile discriminatory practices to persist”. For example, Strayhorn and Mullins (2012) in their research on Black gay students found residence hall policies and programming perpetuated heterosexist, homophobia, and isolation. Similarly, Harwood et al. (2012) found that students identifying as African American, Asian American, Latino, and Native American experienced over 70 distinct racial microaggressions while living in residence halls. These studies highlight the issue of discrimination embedded in a lack of safety and security narrative.

Graham, Hurtado and Gonyea (2016) purport that living in residence halls is often anecdotally associated with gains in students' academic development, although the research in this area is less certain. In his meta-analysis of 21 studies that compared residence hall students with those living at home, Blimling (1989) found students living in residence halls seem to perform better academically than students who live at home (Rinn 2004). The residence hall then becomes the "psychological home and the locus of identity development during the most concentrated and intense learning period in the lives of students” (Hughes 1994, 191, quoted in Rinn 2004). 
Taking into consideration South Africa's commitment to transforming its socio-political landscape then providing student accommodation that resonates with the "psychological home and the locus of identity development during the most concentrated and intense learning period in the lives of students" should be an important imperative. This notion of a home away from home coincides with findings from a task team that emphasised that student accommodation and residences are "living social communities that can either advance or detract from our shared university or societal goals” (SAHR 2016).

Findings from the Eurostudent (2011) study reported that financial concerns with accommodation as part of students' living expenses may have a negative impact on equity of access to higher education, especially for those potential students from families with lower income. This finding resonates largely with the socio-economic status quo of the majority of South Africans. One important research output contained in the Eurostudent report (2011) bear's further relevance to the South African scenario. The report emphasised that, first, student housing is a significant variable in students' academic life, and that, second, funding for such accommodation plays a key role in the selection of student housing. In essence, therefore the capacity of the state to fund accommodation will determine the quality of accommodation that HEI's provide. In turn good quality accommodation should have a positive is impact on student's academic success. The Soudien report (DoE 2008) recommended that research needs to be conducted to explore the broad and complex relationship between student housing and academic success.

A further recommendation from the Soudien Report (DoE 2008) noted that "research needs to be conducted to explore ways in which the social and cultural milieu in residence systems affects the ability of black working-class students to succeed academically”. Again, to improve black working-class community's socio economic status by increasing access to and opportunity within higher education also demands quality student accommodation. Quality accommodation that meets the learning styles of students enhances student success. If the South African State is serious about transforming society through the academic success of students then it must invest in safe, adequately resourced accommodation. The Department of Higher Education and Training (2011) maintains that "whilst there is a complex relationship between student housing and academic success, there is preliminary evidence to suggest that being housed in a safe, well-managed residence does advantage students, particularly those from poorer backgrounds”.

The increased demand for quality accommodation in South African higher education sector has been a serious matter of contention amongst students and student bodies. Between 2009 and 2013, alone South African higher education experienced thirty-nine student protests 
over student housing (Jansen and Dube 2013). Following these protests the Minister of Higher Education, Blade Nzimande, in 2011 set up a task team to investigate the national student housing crises. The specific objective of the task was to establish the scale and magnitude of student accommodation challenges and to offer a well-motivated and justifiable differentiated framework for redressing the student accommodation quandary. The task team (mentioned above) concluded that student housing in South Africa must be of an enabling nature. They also found that the severe shortage of residence accommodation meant that the vast majority of students who seek off campus accommodation are often housed in unsafe areas in unacceptable conditions (South African Higher Education Reviewed, CHE 2016). Hence the task team emphasised the fact that student accommodation and residences are "living social communities that can either advance or detract from our shared university or societal goals” (SAHR 2016).

Similarly, a report done by the Department of Higher Education and Training (2011) supported this and indicated that "being housed in a safe, well-managed residence is both socially and academically beneficial for students, particularly those from poorer backgrounds”. Decent, safe and affordable student accommodation allows students to focus their energies on their academic performance, therefore improving the chances of academic success (Department of Higher Education and Training 2011).

Many South African residence students have had unsafe experiences, some of which have been documented by researchers in the field. For example, following the rape of a foreign student at the University of KwaZulu Natal residences Swartz et al. (2017) conducted a study in which they found safety not only to be a threat in UKZN but for many students across various universities in South Africa. Their study did however highlight UKZN students being particularly concerned with safety even though three years earlier the matter was raised with university management. A report done by the Department of Higher Education and Training (2011) indicated that "without effective leadership, management and administrative structures, programmes, codes and interventions which facilitate and provide supportive learning environments, actually constitute barriers to student learning and academic success”. Similarly, the Eurostudent report (2011) maintained that student housing is a significant variable in students’ academic life. Parameswaran and Bowers (2014) maintain that spending up to 20 hours a day in a residence has a definite impact on learning; the key question has always been whether the positive factors outweigh the negatives, and how the positive factors can be enhanced.

Resultantly in September 2015 the Ministry of Higher Education gazetted a policy on Minimum Norms and Standards for Student Housing at Public Universities (DHET 2015). The application of these norms and standards was to ensure that students are provided with adequate, 
fit-for-purpose accommodation of reasonable quality and that they enjoy learning and living environments that promote academic success. Although not very explicit, the norms and standards allude to safety and security of students as a key component in quality residences for students.

\section{THEORETICAL APPROACH}

Piquero and Hickman (2003), Schreck (1999), and Stewart, Schreck and Simons (2006) maintain, "a notable area of success in applying theory is the systematic investigation of individual antecedents to victimization and, in particular, the role of low self-control”. Indeed, the application of self-control to the study of victimization has received significant empirical attention in the past decade from Schreck (1999) and others (e.g., Baron, Forde and Kay 2007; Kerley, Hochstetler and Copes 2009; Piquero et al. 2005; Schreck, Stewart and Fisher 2006; Schreck, Wright and Miller 2002; Stewart, Elifson and Sterk 2004). Specifically, Schreck (1999) suggested that, like offenders, victims engage in high-risk behaviours that often take place in close proximity to perpetrators, which enhances their property and personal vulnerability, highlighting their attractiveness as targets for crime. For the purposes of this specific article, the researchers identified routine activities theory and risk environment theory to theorize the study.

Routine activity theory, a sub-field of crime opportunity theory, developed by Lawrence E. Cohen and Marcus Felson commonly explains why and how youth are at a heightened risk of being victimized (Cohen and Felson 1979). Since an individual's demographics influence their daily activities, they are predictive of their risk of victimization. Students who lack suitable guardians (lack of authoritative safety measures) are likely targets for criminal victimization. Guardianship can be the physical presence of a person who is able to act in a protective manner or in the form of more passive mechanical devices such as video surveillance or security systems. These physical security measures help limit an offender's access to suitable targets. The essential aspect of routine activities theory is the interaction of motivation, opportunity and targets. In this way, the presence of guardians will deter most offenders, rendering even attractive targets off limits.

The theory argues that available opportunities (unsafe student residences) are an important component in the crime calculus. Felson and Cohen (1980) postulate that criminal activities are a "structurally significant phenomenon" meaning that violations are neither random nor trivial events. Offenders study student behaviors (routine activities) and identify their most vulnerable times to attack them or their belongings. Hence, crime in this instance is dependent on available opportunities to offend. If there is an unprotected target and there are sufficient rewards, a 
motivated offender will commit a crime.

In terms of suitable targets, the choice is influenced by the offender's perception of the target's vulnerability (inadequately secured student residences); the more suitable and accessible the target, the more likely that a crime will occur. The presence of capable guardians (university security measures) is held to deter individuals from offending. Therefore, the presence of opportunity coupled with a lack of guardianship increases criminal motivations and the likelihood of an offence-taking place.

The second theory used in conjunction with the aims of the study is the risk environment theory. Rhodes $(2002,88)$ developed the risk environment framework to extend theorizing on risk production and strategies for risk reduction beyond the individual. The framework conceptualizes risk as socially produced in the interactions between people and their environments (Rhodes 2002, 88). A risk environment refers to the "space whether social or physical in which a variety of factors interact to increase the chances of harm occurring" (Rhodes 2002, 88). The risk environment framework helps researchers, administrators and practitioners to understand the social situations and places in which harm is produced and reduced (Rhodes et al. 2005, 1027).

The risk environment theory emphasis on the understanding of the social situations and places in which harm is produced and reduced. Risk environments are the physical, social, economic and policy which are common for harm to occur (Rhodes 2002), in this instance the social situations and places are located in university residences and the challenge being investigated are the risks faced by the clients namely UKZN students. The service provider is University of KwaZulu-Natal. This theoretical framework provides a theoretical lens that seeks to understand the environmental determinants of harm as a way to creating and enabling an environment for harm reduction in UKZN residences. Criminologist C. Ray Jeffery (1977) underscores the enablement framework by noting that crime and or victimisation results partly from the opportunities presented by physical environment therefore it is possible to alter the physical environment so that crime and or victimisation is less likely to occur.

Similarly, Clarke (1997) maintains that the risk environment theory will highlight situational and structural interventions which create an enabling environment for harm reduction and suggests that much offending can appropriately be viewed not simply as the product of deep social, economic, and psycho-logical causes but also as the result of deliberate choices by individuals. This study examined universities as a risk environment which may contribute to unsafe living conditions, resulting in poor academic performance, since risk is produced in the interactions between individuals and their environments. This approach gives the parallels and vulnerability in general and related harm, by focusing on the issues of 
vulnerability and human rights.

Thus, risk reduction by university administration will reduce opportunities for student risk. This theoretical framework allows the researchers to examine and explore the data from a clientele perspective determining whether the university systems are meeting “their” clientele's satisfaction in terms of residence safety, security and living conditions. According to Rhodes (2009) this theory accepts that there are indeed structural risk environments which are incorporated into the experiences or knowledge received by the students. This is achieved and explained through a thematic analyses approach in the data analysis process.

\section{RESEARCH METHODOLOGY}

The study location is a university in KwaZulu Natal. The university caters to commuting and residence students. Through purposive sampling (within a qualitative methodological approach and research design), participants were identified via residence assistants assigned to the various residences. Participants comprised male and female undergraduate students residing on Howard College and Pietermaritzburg campuses. The data was produced through six (1 x 2) individual focus group discussions planned according to the following criteria; $x 1$ female only group ( $1^{\text {st }}, 2^{\text {nd }}$ and $3^{\text {rd }}$ year students $)$ x 1 male only group $\left(1^{\text {st }}, 2^{\text {nd }}\right.$ and $3^{\text {rd }}$ year students $)$ on each campus. Both groups comprised six participants each. Each group participated in two focus group discussions - an initial focus discussion where they shared information about themselves and the nature of residence life. The second focus group discussion that continued where the first group discussion concluded lasted between 45 minutes to an hour. All participants were requested to sign consent forms, which gave permission for their participation and the recording of interviews (subsequently transcribed verbatim and coded). The researchers used pseudonyms in all instances to circumvent any possible link to participants.

Data was produced through narrative inquiry, which according to (Bleakley 2005) is a form of qualitative research that takes story as either its raw data or its product. While science concerns itself with the establishment of truth, a story's concern is to provide experience with meaning. The "thinking with stories" approach employed in this research study balances consideration of story as discourse and how narratives may be used rhetorically to manage both social interactions and identity (Chase 2005) the narrative inquiry method as it would allow for a detailed explorative investigation into the ways human beings experience the world depicted in their stories (Webster and Mertova 2007). The narrative enquiry method facilitated the telling of student narratives, which provided insight and understanding of participants' feelings about their fears and safety challenges that residences generated owing to inadequate security. 


\section{DATA ANALYSIS}

Using Braun and Clarkes’ (2006) hematic analysis model (three) themes were identified from the transcribed interviews and are discussed below.

\section{Analysis and discussion of findings}

The first theme (theme 1) addresses experiences of general security matters followed by (theme 2) female security experiences and then (theme 3) university security systems.

\section{General Security}

Security challenges have been and continue to pose a threat to students at many universities including the research site in this study. In a commissioned study by Swartz et al. (2017) the researchers concluded that students continue to be critically concerned about security at UKZN which resonates with one participant's view (S1):

"Last semester a girl at Romley (name of a residence) was held at gun point and things were stolen from her room, while the security guards were there."

Others (S3, S6, S7, S8 and S9) added, "Security is a huge issue!"

Yet another respondent (S4) maintained,

“Last year my room was broken into and my laptop was stolen. If you buy a laptop, I’m sure within two weeks it will be stolen. Even when you are in the room. When my room was broken into my laptop was stolen. I had morning lectures and decided not to go, I ended up going at 10h30. This was just one lecture, one lecture!!! For 45 minutes. I asked myself 'how could this happen'. How was it possible, when I was here nothing happened? I just disappeared for 45 minutes and everything is a mess now. It could be someone that you know. Mind you they don't target rooms that don't have laptops; they always go for the ones that have laptops."

For S6 the following stood out, “Talking from experience, last semester some dudes randomly walked in, I don’t know if they were walking around the res but they walked into our kitchen and they took everything from the deep freezer, food etc. you can imagine we had meat there and burgers. And they just took everything.” These respondents indicate that nothing seems safe in this environment. Residences appear unsafe and unconducive for study because students lost valuable assets including technological gadgets, which augment their studies. These findings are further supported by a News 24 report, which claimed, “Today in many campuses in South Africa, especially at the residences, security is almost non-existent. Students come in and out as they please. Outsiders gain entry without any trouble in student residences” (News 24, 2008). Yet law, to uphold and ensure safety within the learning environment (Republic of South Africa 1996), compels academic institutions to comply. Further South Africa ranked last 
in terms of safety in comparison with 38 other countries (Mullis et al. 2007), thus it is logical to ensure maximum safety and security on South African campuses. Resultantly this will allow students to study to their full academic protentional free from feelings of anxiety and stressful living conditions. From the above analysis, it is clear that the university in this study is not providing a safe learning environment conducive to academic success.

Similarly, findings from a study conducted by Swartz (1998) supports the above findings. Swartz maintained that student residences are of strategic importance because they are ideal locations for both teaching and learning and social and recreational life, not least because they can create a sense of community. In the same vein (Astin 1984; Chickering 1974; Pascarella 1984; Pascarella, Terenzini and Blimling 1994; Welty 1976) assert that "residence halls promote a variety of desirable academic outcomes by enhancing students' involvement and engagement with their institutions”. Findings, from a study on social cohesion in higher education institutions in South Africa (DoE 2008) purported that elements of residence life, such as "drinking and sexual harassment detract from creating an environment suited to learning”. The study found that on-campus student residences are frequently poorly governed and managed or even not at all governed and managed. Many staff in charge of accommodation have not had the requisite training to manage their responsibilities, resulting in incompetent practices or simply inaction.

Thus, instead of always providing students with the best environments, on- or off-campus, within which they can flourish and achieve their, their families' and our ambitions, universities are simply reproducing the cycle of incompetence, lack of compassion and poverty. Residences located in university campuses are much more than bricks and mortar. They are living social communities that can either advance or detract from our shared university or societal goals. Residences must become an integral part of the academic project and promoted as sites of academic endeavours (DoE 2008).

\section{Female security experiences}

A further finding, especially with female respondents, was lack of trust in security guards and anxieties experienced by some as some female participants (S1, S3 and S6) reported:

\footnotetext{
"You cannot study when you don’t feel safe, because you are scared that something bad may happen to you."

S6 also claimed, "When I go home for a few days, my roommate never sleeps alone in the room. She sleeps in her friends' room because she is scared to sleep alone.”
}

Another respondent (S2) recounted her incident, 
"My roommate saw these guys while she was walking out her friend's room. As she walked into the kitchen she saw the guys. She just thought they were there for their friend or something so as she opened the deep freezer she noticed that it was empty, empty, empty! And luckily I was in my room and she said somebody stole all our food. So I was like, how is this possible? So I walked out of my room and as I was walking I saw the guys up there with our food and we just knew it was them. Luckily we had this other dude and he chased the guys and we got our food back.”

One respondent (S11) was bold enough to blame fellow students for their victimisation,

\begin{abstract}
"Personally I believe the fault lies on the students because we have people standing at the gates asking to be swiped in and we don't even know whether they are students at UKZN or strangers from outside. You will never know whether they swiping in a serial killer ... you will just never know. This thing really annoys me! I think if a friend is coming over I think they should call you to please come at the gate so you can swipe them in, so we don't have people standing at the gate asking to be swiped in.”
\end{abstract}

The pressure of performing academically while at university is tough, especially for students emerging from system. Focussing energy on safety and security matters that should be taken care of by university administration should be seen as a constitutional violation of students whose mandate is to successfully exist the tertiary landscape in minimum time (Sass 2005). The university's violation is further confirmed by case law that reveals three general principles underlying institutional responsibility and liability in the area of campus safety. The first is special relationship, whereby institutions are expected to possess both a commitment to the safety and general welfare of their students and an obligation to provide appropriate levels of security to promote their safety (the "duty of care” doctrine). The second principle in relation the above-mentioned routine activities theory, is foreseeable risk, whereby colleges and universities have a duty to provide protection from foreseeable injury or criminal acts; and the third contractual obligation, whereby institutions are expected to follow through with any commitments, both explicit and implicit, made with members of the community in regard to their enhanced duty to protect said members (Burling 2003; 1991).

Clearly from participants' responses the university is in violation of students' right to safety. Psychologically this cannot be easy. Student belongings are valuable and necessary for academic success. Replacing belongings in the absence of insurance cannot be an easy task for parents. Further instead of having to worry about safety and security students should have the freedom to focus on their academic careers.

A study conducted by Mabaso et al. (2015) supported the above findings, that students are vulnerable and are living in unsafe conditions, their findings indicated that the majority of female students (94\%) felt some degree of unsafety on campus and in res, the greatest fear for 
these women was sexual assault, followed by verbal, physical and emotional assault. The feelings of vulnerability and concerns of safety in the living conditions of these women are justified as literature findings of media reports (SAPA 2008; News 24 2008) have demonstrated incidences of rape of female students at Rhodes University, UKZN and Durban University of Technology.

\section{University security systems}

On the contrary one view (S10) was,

"I think that the problem lies with housing because all they tell us to do is sign a contract and nothing else. When your laptop gets stolen, the first question they ask you is 'do you have insurance'. When you get here for application they don't tell you that there are some rules here: here they do have robbers in the res and that we should pay for insurance for our laptops.”

Another respondent (S2) complained,

"Even the cameras they have around res, they don't work."

"There is no proper communication between housing and the security system. When you go to housing, they tell you go to the security. When you get to security, they tell you go back to housing. Then you wait the whole day for the police to come, and when they come, you have already touched everything when they want to check for fingerprints. Even that investigation can go on for the whole year. I had my laptop stolen in first year and the investigation is still continuing."

"I remember this one time one of the student's laptop was stolen in Malhob (name of residence) so he had to go to RMS and he reported everything there. He asked them if they could check through their camera footage if they could see something and they did. You know what they said. They said the cameras are unable to see the face. I don't know the technology with their camera ... actually it's a mess, it's not working."

"I had my stuff stolen and when I got there they only had a record of like 10 seconds. During the time I had my laptop stolen they said the cameras were not working. I think it's just something that's recorded. When you get there, they just show you something to appease you. It's really just for formality."

The level of security services, according to participants, are highly questionable (Wills, Hines and Johnson 1994). The university as a service provider appears not to provide the quality of safety that is deemed appropriate for a living and learning environment. A theoretical interpretation of the risk environment framework helps understand the impacts of the loss of necessary valuable material as such as laptops, resulting from poor security will inevitably effect academic productivity and efficiency. Furthermore, the psychological anxieties, resulting from living in stressful unsafe conditions undoubtedly will hamper a student's ability to perform to the best of their academic potential. The risk environment framework supports, that these 
impacts and effects can result from social situations and places in which harm is produced (Rhodes et al. 2005, 1027). The Eurostudent report (2011) further supports these findings and emphasises that, first, student housing is a significant variable in students' academic life, and that, second, funding for such accommodation plays a key role in the selection of student housing. Adequate accommodation is - together with sufficient funding - a main framework condition for the "smooth operation" of studies. Financial concerns with accommodation as part of students' living expenses may have a negative impact on equity of access to higher education, especially for those potential students from families with lower income. For instance, students may have to make a choice between remaining with their parents and studying in the university nearest to this address or choosing an alternative study location, but having to work during studies to cover the expenses for rent (Eurostudent 2011, 168)

S6 confirmed the poor status of camera recordings,

“There's not enough cameras. When my friend's laptop was stolen. The only thing they told her was that they could see the guy going in with the bag and then he's coming out and that's it. They just lost him somewhere, no sign of him on any of the other cameras.”

Cameras are not only inadequate in terms of quality this effects the "guardianship" as identified in the above theory. Another respondent commented on the quality of security services,

"The other thing I heard about the Risk Management Services (RMS) is that their system is able to detect when a student enters and leaves and whether the student is swiping for example 7 people at the same time, it's able to tell that something is happening which is not usual. They can immediately block access on you card, but they don't do that. I've seen guys swiping 10 people in.”

For this participant RMS appears ineffective in light of technology available to be proactive and limit opportunities for an unsafe environment. Another respondent (S3) recounted her initial experience,

"When I came to this varsity I had a bad experience. I'm not trying to compare this varsity with the previous one I went to, but at times I do compare. My previous varsity, the security was okay. Every day you felt safe, even if you leave your room open, you'll find your stuff there. But here we have a system ... starting with the reses, you can even open the room without using a key. Another thing, the security guards are really just teddy bears by the gates. They are just there with their navy uniform and nothing else."

"I remember someone's room was broken into and she happened to notice who was in her room. She was in the kitchen and her room was locked. When she came back her room was open and she saw the guy. She chased after the guy. The guy was about to go out the gate he didn't have a card. As she was chasing after him, she was also shouting 'stop that guy!' The RMS instead of stopping that guy, he swiped that guy out.” 
However, from the above data, the lack of high quality security is being questioned again. Gaining access to rooms without the use of keys renders students vulnerable and may only increase safety risks.

The idea that RMS staff cannot protect students “what student's want” is cause for great concern. The incidences that respondents (S2, S5, and S9) related were,

(S2) "In first year my room was broken into for the second time, this time they just cut the padlock. I first went to the security and asked to see any footage, but they said the cameras were not working. But funny enough they were working until 9am and this happened around 10am and then after that they started working again. Second thing is when I went to report the matter, I was told to collect the padlocks that were cut off. We can't rely on RMS. There should be a student forum on crime.”

(S5) "When it comes to the varsities property being stolen the criminals will always be caught, but when it comes to students, they don't mind. There were two incidences last year. Two computers were stolen from the Agriculture lan and a guy was found carrying them somewhere at OMB and then they could easily see him on the cameras and they tried to catch him. Yet, when it comes to student's belonging that does not happen.”

Another respondent (S7) claimed,

"I think we have laws that contradict each other on the security system. On campus and res grounds, you are not allowed to have any form of weapons. So RMS having any form of weapon is a contradiction of the laws. Why implement the law on the RMS that only gives a disadvantage to us as students, because those laws are not helping us in any way. There is one instance were an RMS staff was walking a girl from campus to res and these guys came up wanting to rob them. The RMS didn't do anything, he ran. The RMS just ran away and they took the phone and left.”

For (S9) the SRC has a particular role to play which she expressed as,

“The student union's first mandate should be the security. Not only the reses, but the whole campus and make it a priority. It's something that's always happening constantly and we have a lot of instances when it occurs. Personally, when they have their next strike I'm going to just say 'put in some security right there'.”

Other respondents (S1 and S11) commented on discriminatory practices of the RMS related to foreign students for example (S11),

“For me the first time I had my laptop stolen, the first question was, 'are you South African?'. When I said I am not, they said I was supposed to pay insurance. When an international student comes, they don't send a letter saying things about insurance; you need your own security yet here in WOB (name of residence) we have some guys from America. Last year two of them lost their Apple laptops. When they went to housing, housing managed to buy those laptops. But we also have the other students around here, maybe from Zimbabwe. If they go there and report, they will get that question (are you South African).” 
S1 added,

“The same day the American's laptops were stolen, it's the same day mine was stolen. Theirs were bought brand new, mine is still being investigated. They should tell us to pay insurance then because we are not Americans.”

Participants' perceptions of some foreign students receiving preferential treatment is a cause for concern. University administration is either discriminating through policies or staff are not trained in ensuring consistent, fair and equal treatment.

\section{LIMITATIONS OF THE STUDY}

Access to respondents according to the research design-sampling frame was a challenge due to the slow response of the staff involved with student residence matters. Co-ordinating focus group discussions to dovetail with the groups' availability also proved challenging. The findings of the study are not generalizable owing to the sample size. However, it in no way invalidates the findings of the study. It indeed opens the space for dialogue and future research on the topic.

\section{CONCLUSION AND RECOMMENDATIONS}

The findings categorically indicate a gross constitutional violation as participants claimed and showed unsafe residences. Participants clearly accentuated through their experiences the "perceived indifferent" attitude of university administration who appear not to formally evaluate their services from a key stakeholder (students). Responses have provoked many more questions that require further research and a replication of the study.

From the above analysis, it is evident that students staying on campus, the quality of their residence experience is an important factor in their chances of success. The 2012 report on student accommodation, prepared by a task team appointed by the Minister, described severe overcrowding and "squalid conditions" endured by many students. Students who are malnourished and hungry are clearly not going to perform well in their studies; such a situation should not be allowed for "both moral and academic reasons". Swartz indicates that since 1994 universities have been increasingly pitted against each other.

A theoretical interpretation of the findings supports, that crime patterns in relation to archetypal and foreseeable activities of the target generate anticipatable opportunities for an offender to commit an unlawful offence (Felson and Cohen 1980). Therefor it can be concluded that ideal opportunities are created for criminal conduct when targets engage in risky behaviour; for instance, being vulnerable - such as res showers. One such is the apparent need for large 
scale quantitative research that evaluates safety and security of university systems and programs for students. The data analysis further highlighted concerns with issues of safety and security in residences specifically and access of non-university students into campus generally. Since they illustrated this as a major concern one of the key recommendations of this study is to ensure firstly stricter access control, better security systems for individual rooms and an increase in the number of visible security guards at each residence. University administration should engage students first hand to listen to their worries and fears around safety in residences. Clearly students' mandate is to study and university administration is to provide a learning space free of fear and anxiety.

\section{REFERENCES}

Astin, A. W. 1984. Student involvement: A developmental theory for higher education. Journal of College Student Personnel 25: 297-307.

Baron, S. W., D. R. Forde and F. M. Kay. 2007. Self-control, risky lifestyles, and situation: The role of opportunity and context in general theory. Journal of Criminal Justice 35: 119-136.

Bleakley, A. 2005. Stories as data, data as stories: Making sense of narrative inquiry in clinical education. Medical Education 39: 534-540.

Blimling, G. S. 1989. A meta-analysis of the influence of college residence halls on academic performance. Journal of College Student Development 30: 298-308.

Burling, P. 1991. Crime on campus: Analyzing and managing the increasing risk of institutional liability. Washington, DC: National Association of College and University Attorneys.

Burling, P. 2003. Crime on campus: Analyzing and managing the increasing risk of institutional liability. $2^{\text {nd }}$ Edition. Washington, DC: National Association of College and University Attorneys.

Braun, V. and V. Clarke. 2006. Using thematic analysis in psychology. Qualitative Research in Psychology 3(2): 77-101. ISSN 1478-0887. http://eprints.uwe.ac.uk/11735

Chase, S. E. 2005. Narrative inquiry: Multiple lenses, approaches, voices. In The SAGE handbook of qualitative research, ed. N. K. Denzin and Y. S. Lincoln. London: SAGE Publications.

Chickering, A. 1974. Commuting versus residential students: Overcoming educational inequities of living off campus. San Francisco: Jossey-Bass.

Clarke, R. V. 1997. Situational crime prevention: Successful case studies. $2^{\text {nd }}$ Edition. Albany, NY: Harrow and Heston.

Cohen, L. E. and M. Felson. 1979. Social change and crime rate trends: A routine activity approach. American Sociological Review 44: 588-608.

Department of Education. 2008. Report of the Ministerial Committee on Transformation and Social Cohesion and the Elimination of Discrimination in Public Higher Education Institutions. Pretoria. Soudien Report.

Department of Higher Education and Training. 2011. Report on the Ministerial Committee for the review of the Provision of Student Housing at South African Universities. Pretoria.

Department of Higher Education and Training. 2015. The Policy on the Minimum Norms and Standards for Student Housing at Public Universities. Government Gazette 29 September 2015. No. 39238.

DHET see Department of Higher Education and Training.

DoE see Department of Education.

Eurostudent. 2011. Social and economic conditions of student life in Europe: Synopsis of indicators. 
(Eurostudent IV 2008-2011). Hannover: Hochschul-Information's-System. http://www.eurostudent.eu/results/reports (Accessed 1 August 2016).

Felson, M. and L. E. Cohen. 1980. Human ecology and crime: A routine activity approach. Human Ecology 8(4): 389-405.

Graham, P. A., S. S. Hurtado and R. M. Gonyea. 2016. Living on campus: Does it still make a difference? Centre for Postsecondary Research, Indiana University Bloomington. http://nsse.indiana.edu/ pdf/presentations/2016/ACPA_2016_Graham_et_al_paper.pdf (Accessed 13 September 2017).

Harwood, S. A., M. B. Huntt, R. Mendenhall and J. A. Lewis. 2012. Racial microaggressions in the residence halls: Experiences of students of color at a predominantly white university. Journal of Diversity in Higher Education 5(3): 159-173.

Hughes, M. 1994. Helping students understand and appreciate diversity. In Realizing the educational potential of residence halls, ed. C. C. Schroeder and P. Mable, 190-217. San Francisco, CA: Jossey-Bass.

Jansen, L. and A. Dube. 2013. "R1bn for KZN student housing”. The Mercury 13 February 2013. http://www.iol.co.za/news/south-africa/kwazulu-natal/r1bn-for-kzn-student-housing-1.1469498 (Accessed 22 September 2014).

Jeffery, C. R. 1977. Crime prevention through environmental design. $2^{\text {nd }}$ Edition. Beverly Hills, CA.: Sage.

Kerley, K. R., A. Hochstetler and H. Copes. 2009. Self-control, prison victimization, and prison infractions. Criminal Justice Review 34: 553-568.

Mabaso, B., S. Singh, A. Singh-Pillay and R. Mudaly. 2015. Scary living and learning spaces: Female students' perspectives. University of Kwa-Zulu Natal.

Mullis, I., M. Martin, A. Kennedy and P. Foy. 2007. PIRLS 2006 International Report. http://pirls.bc.edu/pirls2006/intl_rpt.html (Accessed 6 August 2017).

News 24. 2008. SA universities "not safe". https://www.news24.com/SouthAfrica/News/SAuniversities-not-safe-20080512?cpid=3 (Accessed 4 August 2017).

Palmer, C., E. M. Broido and J. Campbell. 2008. A commentary on the educational role in college student housing. http://www.tarleton.edu/housing/Documents/EducationalRoleinCollegeStudent HousingCommentary.pdf (Accessed 22 September 2014).

Pascarella, E. 1984. Reassessing the effects of living on campus versus commuting to college: A causal modeling approach. Review of Higher Education 7: 247-260.

Pascarella, E. and P. Terenzini. 2005. How college affects students (Vol. 2): A third decade of research. San Francisco: Jossey-Bass

Pascarella, E. T., P. T. Terenzini and G. S. Blimling. 1994. The impact of residential life on students. In Realizing the educational potential of residence halls, ed. C. C. Schroeder and P. Mable, 22-52. San Francisco: Jossey-Bass.

Piquero, A. R. and M. Hickman. 2003. Extending Tittle's control balance theory to account for victimization. Criminal Justice and Behavior 30: 382-301.

Piquero, A. R., J. MacDonald, A. Dobrin, L. Daigle and F. T. Cullen. 2005. Studying the relationship between violent death and violent rearrest. Journal of Quantitative Criminology 21: 55-71.

Rinn, A. 2004. Academic and social effects of living in honors residence halls. http://digitalcommons.unl.edu/cgi/viewcontent.cgi?article=1153\&context=nchcjournal (Accessed 11 September 2017).

Rhodes, T. 2002. The 'risk environment': A framework for understanding and reducing drug-related harm. International Journal of Drug Policy 13: 85-94.

Rhodes, T. 2009. Risk environments and drug harms: A social science for harm reduction approach. International Journal of Drug Policy 20: 193-201.

Rhodes, T., M. Singer, P. Bourgois, S. R. Friedman and S. Strathdee. 2005. The social structural production of HIV risk among injecting drug users. Social Science \& Medicine 61(5): 1026-1044. 
Republic of South Africa. 1996. Constitution of the Republic of South Africa. Pretoria, South Africa: Government Printer.

SAHR see South African Health Review.

SAPA. 2008. Politicians were out in force yesterday, trying to bring calm to a nation gripped by violence and intolerance: An African day of shame for South Africa. The Star: 3.

Sass, B. V. 2005. Coping with violence: Institutional and student responses at the University of the Western Cape. University of Western Cape.

Schreck, C. J. 1999. Criminal victimization and low self-control: An extension and test of a general theory of crime. Justice Quarterly 16: 633-654.

Schreck, C. J., E. A. Stewart and B. S. Fisher. 2006. Self-control, victimization, and their influence on risky activities and delinquent friends: A longitudinal analysis using panel data. Journal of Quantitative Criminology 22: 319-340.

Schreck, C. J., R. A. Wright and J. M. Miller. 2002. A study of individual and situational antecedents of violent victimization. Justice Quarterly 19: 159-180.

South African Health Review. 2016. From: https://www.health-e.org.za/wp-content/uploads/2016/05/ South-African-Health-Review-2016.pdf (Accessed 10 September 2017).

South African Higher Education Reviewed. CHE. 2016. Two decades of democracy. http://www.che.ac.za/sites/default/files/publications/CHE_South\%20African\%20higher\%20educ ation\%20reviewed\%20-\%20electronic.pdf (Accessed 22 September 2016).

Stewart, E. A., K. Elifson and C. Sterk. 2004. Integrating the general theory of crime into an explanation of violent victimization among female offenders. Justice Quarterly 21: 159-182.

Stewart, E. A., C. J. Schreck and R. L. Simons. 2006. “I ain’t gonna let no one disrespect me”: Does the code of the street reduce or increase violent victimization among African American adolescence. Journal of Research in Crime and Delinquency 43: 427-458.

Strayhorn, T. L. and T. G. Mullins. 2012. Investigating black gay male undergraduates' experiences in campus residence halls. Journal of College and University Student Housing 39(1): 140-161.

Swartz, L. 1998. Culture and mental health: A Southern African view. Cape Town: Oxford University Press.

Swartz, S., A. Mahali, E. Arogundade, E. S. Khalema, C. Rule, A. Cooper, A. Molefi and P. Naidoo. 2017. Ready or not! Race, education and emancipation: A five-year longitudinal, qualitative study of agency and impasses to success amongst higher education students in a sample of South African universities. Client report submitted to the Centre for Critical Research on Race and Identity, University of KwaZulu-Natal/Department of Higher Education and Training.

Webster, L. and P. Mertova. 2007. Using narrative inquiry as a research method: An introduction to using critical event narrative analysis in research on learning and teaching. London: New York: Routledge.

Welty, J. 1976. Resident and commuter student: Is it only the living situation? Journal of College Student Personnel 17: 465-468.

Wills, S. B., E. R. Hines and W. G. Johnson. 1994. Residence hall security as perceived by students and parents at two public universities. Journal of College and University Student Housing 24(2). 